American Journal of Agricultural and Biological Sciences 1 (1): 6-9, 2006

ISSN 1557-4989

(c) 2006 Science Publications

\title{
Financial Assessment of a new Soil Heating Technology for Off-season Asparagus Production
}

\author{
${ }^{1}$ Luce A., ${ }^{2}$ K. Mattas, ${ }^{3}$ I. Tzouramani, ${ }^{4}$ G. Paroussi, ${ }^{2}$ E. Tsakiridou and ${ }^{2}$ E. Raptou \\ ${ }^{1}$ Mediterranean Agronomic Institute, PO Box 85,731 00 Chania, Greece \\ ${ }^{2}$ Department of Agricultural Economics, Aristotle University of Thessaloniki \\ P.O. Box 225, 54124 Thessaloniki, Greece \\ ${ }^{3}$ gricultural Economics and Policy Research Institute, 5 Parthenonos str., \\ 14121 Neo Iraklio, Athens, Greece \\ ${ }^{4}$ Agricultural Research Center of Northern Greece, P.O. Box 312, 57001 Thermi, Thessaloniki, Greece
}

\begin{abstract}
The financial effectiveness of a soil heating system placed under the crowns in each raised bed (UCR) of Asparagus plants (Asparagus officinalis L.) was evaluated and then compared with a traditional greenhouse production system (TPS), a plastic greenhouse without any heating system, in northern Greece. Several appraisal approaches, such as net present value, net present value adjusted for inflation and benefit/cost ratio, were used to evaluate the effectiveness of UCR system for off-season Asparagus production. Results demonstrate the importance of UCR system in terms of volume of production, gross returns and overall effectiveness. Finally, the performed sensitivity analysis indicates that product price variations alter the accrued benefits.
\end{abstract}

Key words: Asparagus officinalis L., greenhouses, economic analysis, Greece

\section{INTRODUCTION}

The worldwide increase in consumer demand for off-season horticultural production has brought a significant expansion of greenhouse cultivation. Greenhouse production in Greece has gone through significant changes as new technologies have been introduced and employed. However, the introduction of any new technology should be accompanied by a thorough assessment of its profitability and effectiveness ${ }^{[1]}$. In this respect, new technologies attract the interest of practitioners and investors particularly in today's world where technology adoption determines the level of competitiveness in farm production ${ }^{[2,3]}$.

Asparagus officinalis $L$., native to Europe, grows commercially in temperate and tropical climates ${ }^{[4]}$ and appears a demand increase throughout the world ${ }^{[5]}$. Although off-season Asparagus cultivation is an inputintensive activity, farmers have turned to Asparagus mainly due to its sharp demand increase ${ }^{[6]}$. Europe obtains the largest share of world's Asparagus acreage (52,500ha) followed by North America (45,500ha). EU' production made up $9 \%$ of the world's production while most of Europe's total production is produced in Spain (30\%), Germany (18\%), France (15\%), Italy (15\%) and Greece $(14 \%)^{[7]}$.

This study attempts to evaluate the financial feasibility of a soil heating system under the crowns in each raised bed (UCR) for off-season Asparagus production in plastic greenhouses ${ }^{[8]}$. More specifically, the study assesses the potential investment profitability of the UCR versus the traditional production system (TPS) without any heating system. Production, gross returns and net cash flows are recorded and compared between these two systems providing substantial information to farmers' decision making.

\section{MATERIALS AND METHODS}

The data were obtained from experiments conducted during 1997-98 and 1998-99 at the Agricultural Research Center of northern Greece, located in Thessaloniki, a semiarid Mediterranean region. Two production systems of Asparagus were employed, the UCR and the TPS, in a plastic unheated greenhouse. Technical data were obtained from the experiment while Asparagus product prices were obtained from Asparagus farmers association as it keeps detailed information on product prices.

A round, arch-type polyethylene covered greenhouse with vertical sidewalls (single-span) was used and the greenhouse area was approximately 163.2 $\mathrm{m}^{2}$. The soil was heated with hot water originating from a central bio-mass burner system. Hot water was circulated in two pipes ( $2.54 \mathrm{~cm}$ diameter) placed under the crowns and an unheated bed was used as control ${ }^{[8]}$. Peach cores were burned to obtain an unconventional source of energy (biomass). 
An automatic system was used to adjust the appropriate internal greenhouse temperature and the raised beds were covered with black plastic mulch to ensure the growth of white spears and control the weeds.

For the experimental period of 1997-98, the crowns were planted in the greenhouse on April 17, 1997. All treatments were arranged in a randomized completeblock design with four replications ${ }^{[9]}$. The same cultivars (Dariana, Larac and Steline) were used in both experimental periods. One-year crowns were planted and placed in furrows with a depth of $30 \mathrm{~cm}$ and a distance among them of $170 \mathrm{~cm}$. A total of sixteen furrows were used, with plant distance of $20 \mathrm{~cm}$ in each row. Afterwards, the crowns were covered with rototilling soil. The raised beds were constructed in January 1998 for the first production year and in December 1998 for the second production year (1999) and covered immediately with black plastic mulch. Soil heating began on January 19, 1998 for the first harvesting year (1998) and on December 14, 1998 for the second harvesting year (1999). Soil heating commenced 15-20 days prior to harvest for both experimental periods. Optimal soil temperature was kept between 16 to $18{ }^{\circ} \mathrm{C}$, while temperatures were not allowed to exceed $35^{\circ} \mathrm{C}$. Heating stopped at the end of February in 1998 and the end of January in 1999.

Plant density in the greenhouse was about 2.9 crowns $/ \mathrm{m}^{2}$ (i.e. a total of 2900 plants $/ 0.1$ ha). The same soil mixture for all production systems was enriched by nutrients according to Asparagus nutrition needs ${ }^{[10]}$. Fertilization, drip irrigation and pest control were pursed for both production systems. The spears were sorted out in two classes: extra class (E) and moderate class $(\mathrm{I}+\mathrm{II})^{[10]}$.

Economic assessment: Modern finance theory uses capital budgeting to analyze current investments. The basic concept underlying financial analysis of alternative projects is to compare costs and benefits and determine which project provides the greatest returns ${ }^{[11]}$. The usual technique of comparison is through discounting methods that convert all estimated costs and benefits over the lifetime of the project to values equivalent to the present time ${ }^{[12]}$.

The most commonly employed evaluation technique to determine a project's acceptance is the net present value (NPV). The application of this method involves annual operating expenditures (costs) to be netted against annual inflows (benefits) in order to obtain the project's net cash flows ${ }^{[13]}$. According to Brigham $^{[14]}$, the NPV is the value of the expected net cash flows of an investment, discounted to an appropriate percentage rate less than the initial cost outlay of the project. The corresponding investment decision rule is to accept all the investment projects with positive NPV or a benefit/cost ratio (B/C) greater than one ${ }^{[11]}$.
$N P V=-C_{0}+\sum_{t=1}^{T} \frac{C F_{t}}{(1+r)^{t}}$

(1),

and

$B / C=\frac{\sum_{t=1}^{T} \frac{B_{t}}{(1+r)^{t}}}{\sum_{t=1}^{T} \frac{C_{t}}{(1+r)^{t}}}$

Where $C_{0}=$ initial cost of the project; $C F_{t}=$ net cash flow in year $\mathrm{t} ; \mathrm{r}=$ appropriate discount rate; $\mathrm{T}=$ project's expected life; $\mathrm{B}_{\mathrm{t}}=$ discounted benefits in year $\mathrm{t} ; \mathrm{C}_{\mathrm{t}}=$ discounted costs in year $\mathrm{t}$.

Bartley ${ }^{[15]}$ states that the use of the traditional NPV model may result in inaccurate measurement of the net present values and therefore inaccurate ranking of alternative projects. Thus, a simple modification of the NPV model permits accurate computation of net present values in an inflationary environment. Under an inflationary environment, the NPV expression given by Bartley ${ }^{[15]}$ takes the following form:

$\mathrm{NPV}=-\mathrm{C}_{0}+\sum_{\mathrm{t}=1}^{\mathrm{T}} \frac{\left[\mathrm{IF_{ \textrm {t } }} \prod_{\mathrm{j}=1}^{\mathrm{t}}\left(1+\mathrm{u}_{\mathrm{j}}\right)-\mathrm{OF}_{\mathrm{t}} \prod_{\mathrm{j}=1}^{\mathrm{t}}\left(1+\mathrm{v}_{\mathrm{j}}\right)\right]}{(1+\mathrm{r})^{\mathrm{t}} \prod_{\mathrm{j}=1}^{\mathrm{t}}\left(1+\mathrm{i}_{\mathrm{j}}\right)}$

where $C_{0}=$ initial cost of the project; $I F_{t}=$ expected cash inflow in year $\mathrm{t} ; O F_{t}=$ expected cash outflow in year $\mathrm{t} ; t=$ time period; $\mathrm{T}=$ project's expected life; $u_{j}=$ anticipated inflation rate for cash inflows in period $\mathrm{j}$; $v_{j}=$ anticipated inflation rate for cash outflows in period $\mathrm{j} ; i_{j}=$ anticipated inflation rate for general price level in period $\mathrm{j} ; r=$ risk adjusted discount rate. One of the advantages of the NPV approach in order to adopt new techniques is that fewer data are required.

Sensitivity analysis: Sensitivity analysis determines the degree of change in terms of the project NPV when key variables entering into the financial justification are exposed to unfavorable variances ${ }^{[16]}$. Through sensitivity analysis, the management can investigate only sensitive variables in terms of their effect on returns or costs ${ }^{[17]}$. Sensitivity analysis can provide information on the most and least important factors that influence the outcome and determine the changes in cost and revenue estimates ${ }^{[12]}$. By looking at the whole range of possible outcomes, managers would be able to enlighten all the risk related aspects from undertaking the particular investment ${ }^{[18]}$.

\section{RESULTS AND DISCUSSION}

An eight year project life span was followed in this evaluation as for this time length no replacement expenses for the initial investment are required. Costs and benefits were computed on the basis of 1999 prices. Inflation was assumed to drop each year by $0.5 \%$ for the rest of the project's life (in 1999 the inflation was 
Am. J. Agri. \& Biol. Sci., 1 (1):6-9, 2006

Table 1: Average annual production, gross returns, initial investment and operating costs for the soil heating system under the crowns in each raised bed (UCR) and the traditional production system (TPS) (0.1 ha)

\begin{tabular}{|c|c|c|c|}
\hline System & UCR & TPS & Change with UCR (\%) \\
\hline \multicolumn{4}{|l|}{ Average annual total production (kgr) } \\
\hline Average & 1,051 & 817 & 28.6 \\
\hline Very early ${ }^{z}$ & 560 & 300 & 86.7 \\
\hline Early $^{\mathrm{y}}$ & 739 & 501 & 47.5 \\
\hline Average annual gross returns (\$U.S.) & 9,375 & 6,448 & 45.4 \\
\hline Initial investment (\$U.S.) & 8,104 & 7,297 & 11.1 \\
\hline Average operating costs ${ }^{\mathrm{x}}$ (\$U.S.) & 1,522 & 993 & 53.3 \\
\hline Average cost (\$/plant) & 3.31 & 2.85 & 16.1 \\
\hline Average cost $(\$ / \mathrm{kgr})$ & 9.15 & 10.13 & -9.7 \\
\hline \multicolumn{4}{|l|}{ Market price ( $\$ /$ kgr) } \\
\hline Average & 8.92 & 7.89 & 13.0 \\
\hline Very early ${ }^{z}$ & 10.76 & 10.43 & 3.2 \\
\hline Early $^{\mathrm{y}}$ & 9.90 & 8.95 & 10.6 \\
\hline
\end{tabular}

${ }^{\mathrm{z}}$ Production obtained from January until February (inclusive) is considered to be very early.

${ }^{y}$ Production obtained from January until March 10 (inclusive) is considered to be early.

production (Paraskevopoulou - Paroussi, 1999).

${ }^{\mathrm{x}}$ Expressed as an average of the project's life (8 years).

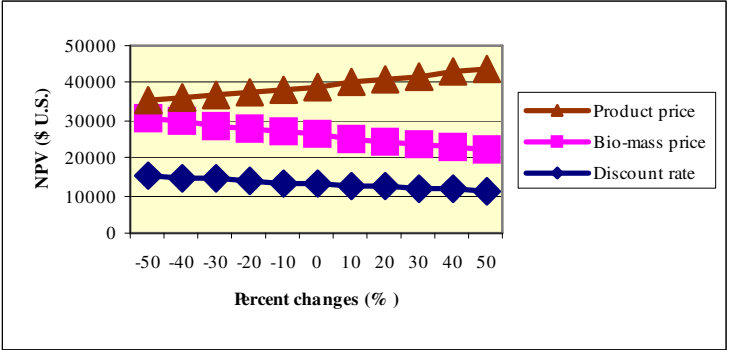

Fig. 1: The effect of a change in discount rate, product price and biomass price on net present value (NPV) of Asparagus grown on $0.1 \mathrm{ha}$

4\%) in accordance to the EU monetary accession requirements. The real discount rate was set at $8 \%$, rate used by the Ministry of Agriculture to discount all agricultural innovative investments, reflecting the risk intense faced by Asparagus investors. Net present values were used to measure the overall investment worth. Finally, sensitivity analysis was applied to determine the main factors that affect the level of income benefits.

Production and gross returns: Total production per year UCR exceeded that of TPS by an average of $28.6 \%$. The annual gross returns obtained from UCR were $45.4 \%$ higher than those obtained from TPS (Table 1) as UCR technique allows early harvest when producer prices are higher. Thus, harvesting production from January to February accounts for 53\% of the total in the case of UCR while in the case of TPS the corresponding number is equal to $35 \%$.

Initial investment and operating costs: Protected cultivation systems, particularly the heated ones, are considered expensive mainly because of the initial construction and soil heating investment. Initial investment expenses, occurred at the first year of production in UCR $11 \%$ higher than in TPS (Table 1). In addition, average annual cost per kilo in UCR exceeds the respective cost in TPS by $9.7 \%$ (Table 1).

Financial analysis: The overall evaluation of UCR in comparison with TPS, using the NPV criterion ended up in a positive NPV $(\$ 13,026)$, implying a significant increase in farmers' income. The NPV adjusted to inflation $(\$ 13,032)$ does not change the results, as the new NPV is almost the same as when inflation is not taken into consideration. Thus, the expected decrease of $3.5 \%$ in the inflation rate has a negligible effect on the measurement of the NPV. In addition, the computed $\mathrm{B} / \mathrm{C}$ ratio was found equal to 4.44 , confirming the results obtained by the simple NPV method. The original outlay of heating investment could be recovered in a very short payback period (less than one year), ensuring the profitability of the investment.

Sensitivity analysis: To perform a more meaningful evaluation of UCR, the effect of a change in certain variables on the estimated NPV was examined. NPVs were estimated by assuming changes in the discount rate, the product price and biomass price (Fig. 1). The ceteris paribus conditions for performing sensitivity analysis were assumed to be the average for the experimental period.

A 10 or $50 \%$ decrease of the discount rate will cause a NPV increase equal to 3 or $18 \%$ respectively. The product price is the most important factor influencing the NPV magnitude. Thus, a decrease in product price of $10 \%$ will cause NPV to fall by $13 \%$ and a decrease of $50 \%$ will lead to a decrease of $65 \%$. Hence, a strong positive linear relation between product price and NPV was observed. On the contrary, the variation of biomass price does not alter significantly the NPV results, as a $10 \%$ price decrease in the biomass price will change NPV by a mere $1 \%$. 


\section{CONCLUSION}

The development and use of the UCR system for off-season Asparagus production constitutes a technological innovation that its adoption in protected cultivation might bring about significant benefits to farmers.

In this study, the effectiveness of the UCR system was assessed by taking into account all the monetary returns and expenses resulting from the installation and operation of the UCR system in an unheated Asparagus greenhouse compared to a TPS system (non-heated) in northern Greece. In addition, the methodology was demonstrated in detail in order to be followed in any case of adopting new innovation technologies.

Results revealed that the implementation of the UCR system in an unheated greenhouse improves the volume of production and the total returns compared to the TPS system. In such cases, the adoption of simple innovative technologies can improve the efficiency in greenhouse production due to indirect effects (earlier harvesting). Thus, the additional cost of such alternative technology can be counter balance by higher market prices due to product quality or earlier harvest. In addition, the present case manifests that financial analysis using experimental data may provide very early indication on the feasibility and profitability of a new technology.

\section{REFERENCES}

1. Salem, A., K. Mattas and M. Grafiadellis, 1993. Assessing low-cost input use in off-season tomato production. Acta Hort., 340: 117-124.

2. Wittwer, S.H., 1993. World-wide use of plastics in horticultural production. Hort. Technol., 3: 6-19.

3. Hochmuth, R.C. and G.J. Hochmuth, 1993. Use of plastic in greenhouse vegetable production in the United States. Hort. Technol., 3: 20-27.

4. Robb, A.R., 1984. Physiology of Asparagus (Asparagus officinalis) as related to the production of the crop. New Zealand J. of Expl. Agr., 12: 251260.
5. Nichols, M.A., 1990. Asparagus - The world scene. Acta Hort., 271: 25-31.

6. Krarup, A., 1996. Proposed planting and production cycle of Asparagus for Ecuador. Acta Hort., 415: 441-443.

7. FAO, 1998. FAO Yearbook-Production. (FAO Statistics. Rome).

8. Paroussi, G., T.V. Koutsos and E. Paroussis, 2002a. Study of heating techniques of soil for forcing outdoor white Asparagus into production. J. Vegetable Crop Prod., 8: 3-10.

9. Paroussi, G., T.V. Koutsos and E. Paroussis, 2002b. Effect of the heating technique on earliness and total yield of three Asparagus cultivars grown in a high tunnel. Acta Hort., 579: 331-336.

10. Paraskevopoulou-Paroussi, G. 1999. Unpublished experimental data. Agricultural Research Center of Northern Greece.

11. Gittinger, J.P. 1982. Economic Analysis of Agricultural Projects. 2nd Edn., Intl. Bank of Reconstruction and Dev., Baltimore.

12 Neale, C.W. and G. Wagstaff, 1985. Discounted cash - flow and life cycle costing for construction projects. Intl. J. of Operation and Prod. Mgt., 5: 55-70.

13. Longmore, D.R. 1989. The persistence of the payback method: a time-adjusted decision rule perspective. Eng. Economist, 34: 185-194.

14. Brigham, E.F., 1985. Financial Management. Theory and Practice. 3rd Edn. Dryden Press, Orlando, Fla.

15. Bartley, J.W., 1980. A NPV model modified for inflation. Mgt. Accounting, 62: 19-52.

16. Eschenbach, T.G. and L.S. McKeague, 1989. Exposition on using graphs for sensitivity analysis. Eng. Economist, 34: 315-333.

17. Singhvi, S.S., 1980. A practical approach to risk and sensitivity analysis. Long Range Planning, 13: 12-19; 49-52.

18. Gratton, C. and P. Taylor, 1986. Project appraisal. Leisure Mgt., 6: 21-22. 